\title{
Glycerol Turnover and Oxidation in Man
}

\author{
Walter M. Bortz, Pavle Paul, Agnes C. Haff, and William L. Holmes \\ From the Division of Research, Lankenau Hospital, \\ Philadelphia, Pennsylvania 19151
}

A B S T R A C T The oxidation and turnover of plasma glycerol has been studied in lean and obese, fed and starving man by means of a long-term infusion of glycerol $-{ }^{14} \mathrm{C}$, and the participation of glycerol in gluconeogenesis has been determined.

Under none of the experimental conditions did glycerol contribute more than $10 \%$ of the total respiratory $\mathrm{CO}_{2}$. Glycerol turnover in fed lean subjects was 106 mmoles/min. Glycerol levels and turnover were higher in the obese subjects and with all subjects after starvation. There was a direct correlation between plasma levels and turnover values for which a regression equation was derived: $y=1556 x+33.1$, when $y=$ turnover in micromoles per minute and $x=$ glycerol level in micromoles per milliliter.

Whereas a direct relation was established between glycerol and FFA levels, the FFA/glycerol turnover ratio was $4.7: 1$ in the lean group indicating incomplete hydrolysis of adipose tissue triglycerides.

During starvation plasma glycerol is nearly or completely converted to glucose in the lean and obese groups, respectively. Of the new glucose formed from protein and glycerol $38 \%$ is derived from glycerol in the lean and $79 \%$ in the obese. Protein and glycerol have been shown to be adequate as precursors to supply at least as much glucose as is being oxidized per day.

\section{INTRODUCTION}

Until recently, glycerol has been generally regarded as a docking site for the metabolically active free fatty acids (FFA) in adipose tissue. Its presence in the blood or in incubation media has usually been considered as a measure of triglyceride hydrolysis (1-3). Relatively scant attention has been paid to the possible oxidative and synthetic fates of glycerol, particularly in man. The role of glycerol in energy metabolism has not been well clarified, especially as compared to the

Received for publication 20 December 1971 and in revised form 30 January 1972. participation of fatty acid. Further, although glycerol has been shown to be an active precursor for glucose in vivo and in vitro (4-8), its participation in human gluconeogenesis has not been quantitated. This role may become important during periods of caloric deprivation. Therefore, to investigate both the participation of glycerol in oxidative metabolism and its role as a precursor for blood glucose, a series of experiments utilizing long-term constant infusion of glycerol${ }^{14} \mathrm{C}$ into lean and obese individuals in the fed and fasting states was carried out.

\section{METHODS}

Subjects. 9 lean and 13 obese subjects participated in this study. The ponderal index

$$
\frac{\text { height in inches }}{\sqrt[3]{\text { weight in pounds }}}
$$

of the lean subjects varied from 13.9 to 12.6 , average 13.3 , while the obese subjects ranged from 11.8 to 9.71 , average 11.1. Two lean and four obese subjects were studied twice. Some of the lean subjects were living in our Metabolic Ward as were all of the obese subjects. All subjects were on a regular diet before the start of a fasting period which varied from $6 \mathrm{hr}$ to 7 days for the lean subjects and up to 35 days for the obese subjects. Fasting was used to obtain a wide range of plasma FFA and glycerol levels.

Procedure. The subject was at rest in a ventilated room during the course of the experiment. Indwelling catheters were placed in the antecubital vein, through which radioactive glycerol was infused, and in the femoral artery, which was used for taking blood samples. The glycerol $-{ }^{14} \mathrm{C}$ (uniformly labeled) $(29.6 \mathrm{mCi} / \mathrm{mmole})$ was prepared for human use by the New England Nuclear Corp. (Boston, Mass.). The labeled glycerol was washed quantitatively from the vial and brought to volume with isotonic saline. At time zero a priming dose was given so that the ratio of priming dose: infusion rate was approximately $150: 1$. The priming dose and infusion (maintained at a constant rate for 7-8 hr using a calibrated Harvard infusion pump, Harvard Apparatus Co., Inc., Millis, Mass.) were adjusted so that the total amount of radioactive tracer administered would not exceed $100 \mu \mathrm{Ci}$ in the lean and $200 \mu \mathrm{Ci}$ in the obese.

Expired air was collected under a plastic hood through which a high airflow was circulated. At timed intervals, the diluted expired air was drawn into Douglas bags by another pump. The $\mathrm{O}_{2}$ and $\mathrm{CO}_{2}$ content was measured by means of 
a calibrated Noyons diaferometer (9). Expired air and arterial blood samples were collected every $60 \mathrm{~min}$ during the first $3 \mathrm{hr}$ and every $30 \mathrm{~min}$ thereafter.

Measurements. The specific activity (SA) of ${ }^{14} \mathrm{CO}_{2}$ was measured according to the method of Fredrickson and Ono (10) as described by us previously (11).

Other workers have remarked on the contamination of plasma glycerol- ${ }^{14} \mathrm{C}$ activity by glucose $-{ }^{14} \mathrm{C}$ activity (8). In recognition of this the following separation and measurement technique was evolved. A protein-free filtrate was prepared from each sample and placed on an Amberlite IRA410 resin (Rohm \& Haas Co., Philadelphia, Pa.) column as previously described (12). The eluate contained all of the glycerol and glucose, whereas lactate and other anionic compounds were retained on the column. A $2.0 \mathrm{ml}$ portion of the eluate was placed in a vial containing $15.0 \mathrm{ml}$ of the solution described by Bray (13) and counted. The radioactivity thus determined was primarily from glycerol and glucose, although, as discussed below, some also occurred in other compounds as yet unidentified. The remainder of the column eluate was incubated with Glucostat (Worthington Biochemical Corp., Freehold, N. J.) for $1 \mathrm{hr}$ to convert glucose to gluconic acid. Then a mixture consisting of zeolite, Lloyd's reagent, $\mathrm{CuSo}_{4}$, and $\mathrm{Ca}(\mathrm{OH})_{2}$, prepared as in reference 14, was added and the sample shaken for $30 \mathrm{~min}$ to remove the gluconic acid. After centrifugation a portion of the supernate was added to Bray's solution for counting.

Glycerol content was determined from another sample of the same supernate by an automated technique as modified from Kessler and Lederer (14) (Fig. 1). The reagents used were identical in concentration to those used in the aforementioned method (14). Additionally, an appropriate amount of unlabeled glycerol was added to the final eluate and the glycerol was isolated as the tribenzoate derivative by the method of Winkler, Steele, Bjerknes, Rathgreb, nad Altszuler (15) and repeatedly recrystallized until a constant SA was maintained. By this method, it was found that about $50 \%$ of the supernatant radioactivity was not from glycerol. The radioactivity of the column eluate and the supernate from the zeolite soda lime treatment were both corrected for this contaminant activity before the SA of glucose and glycerol were calculated.

The validity of this separation procedure was substantiated by means of standard solutions containing appropriate mixtures of ${ }^{14} \mathrm{C}$-labeled glycerol and glucose at concentrations usually encountered in plasma. Total glycerol was consistently recovered, contaminated by $2 \%$ glucose or less.

The levels of glucose and FFA in plasma and of nitrogen in urine were determined as reported previously (12).

Calculations. The turnover rate of the glycerol was calculated from the infusion rate of the tracer and the SA of the plasma glycerol.

Computation of the rate of oxidation of glycerol presents certain difficulties. The SA of the exhaled $\mathrm{CO}_{2}$ rises in the form of an exponential curve approaching an asymptotic value. This rise is due to a slow exchange between the labeled $\mathrm{CO}_{2}$ and the unlabeled bicarbonate pool. The asymptotic value represents the ideal situation in which the exhaled $\mathrm{CO}_{2}$ and the body bicarbonate have the same $\mathrm{SA}$ as the $\mathrm{CO}_{2}$ arising from the tissue oxidation. Issekutz, Paul, Miller, and Bortz provided an equation to estimate the asymptotic SA of $\mathrm{CO}_{2}$ in experiments on humans (16). This equation was established with the help of labeled $\mathrm{NaHCO}_{3}$ and radiopalmitate infusions. In order to estimate the asymptote it was necessary to assume that the $\mathrm{CO}_{2}$ SA derived from glycerol at $450 \mathrm{~min}$ represented $80 \%$ of the asymptotic SA. This assumption made it possible to

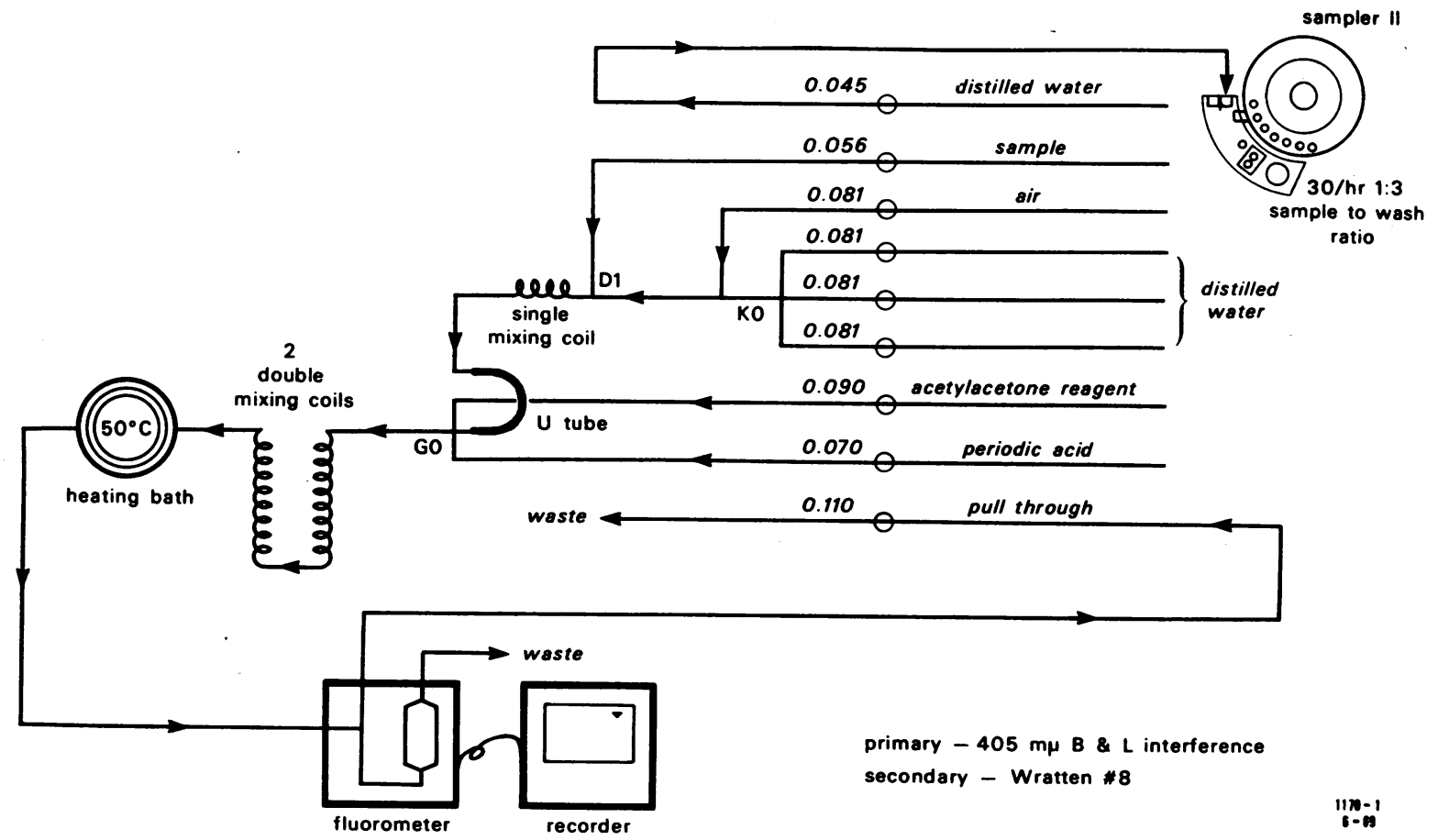

FIGURE 1 Automated assay of glycerol. Concentration range : $0.008-0.040 \mu \mathrm{moles} / \mathrm{ml}$. 
A.

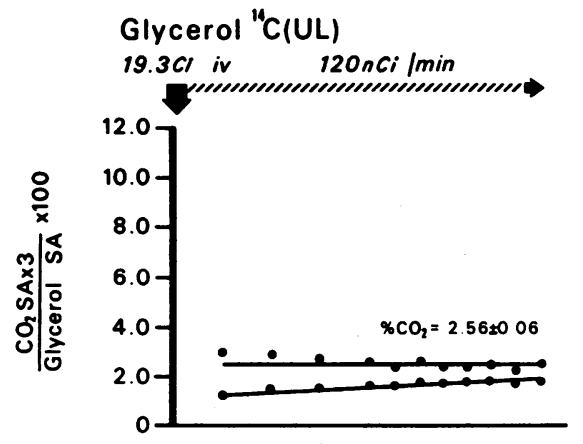

B.
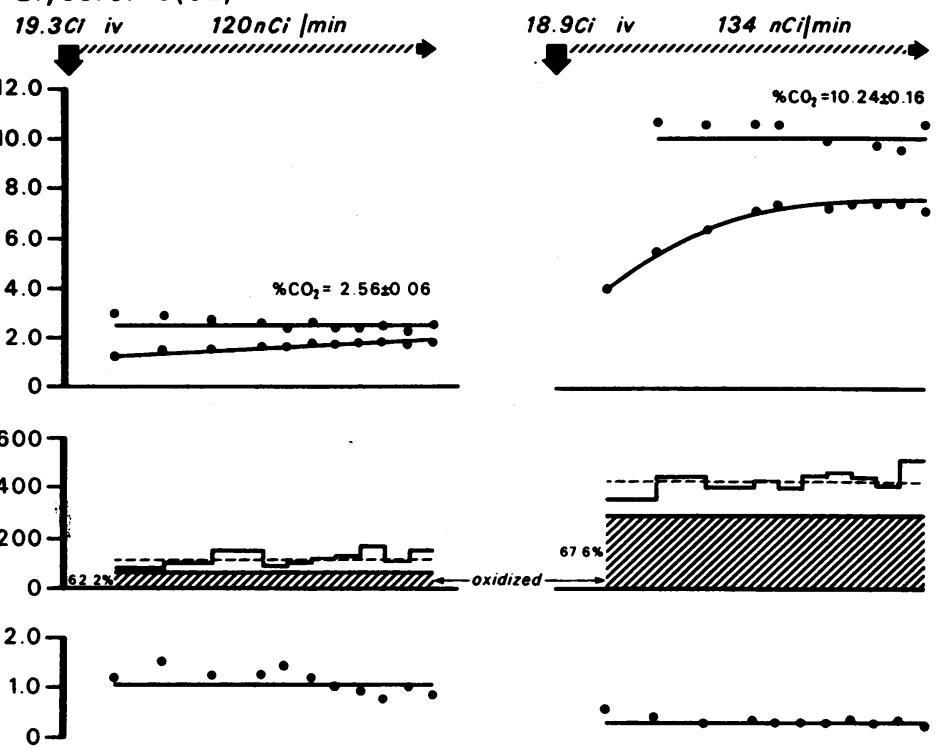

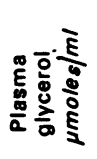

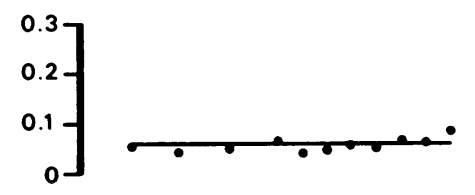

造京

$\left.\begin{array}{c}2.0 \\ 1.0 \\ 0\end{array}\right]$
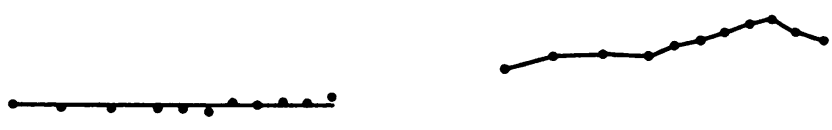

ठั

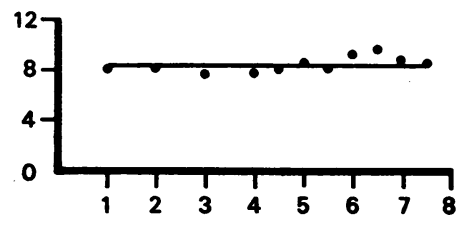

\section{Hours}
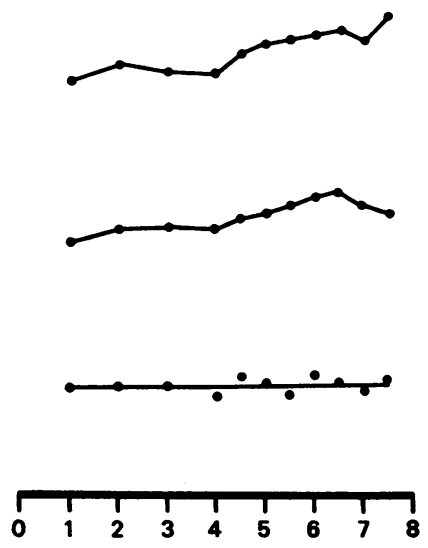

(1214.) $117 \% 0)$

Figure 2 Two experiments, on subjects N. B. $(A)$ and E. J. $(B)$. Estimation of glycerol turnover, oxidation, and per cent $\mathrm{CO}_{2}$ from plasma glycerol. Top graphs represent observed (curvilinear) and calculated ideal asymptotic (straight line) values of per cent $\mathrm{CO}_{2}$ from plasma glycerol.

calculate the best fitting equation of the exponential curve and then to estimate the asymptotic values from each measured point. The asymptotic ratio $\left(\mathrm{CO}_{2} \mathrm{SA} /\right.$ glycerol $\left.\mathrm{SA}\right)$ gives the per cent contribution of plasma glycerol to the expired $\mathrm{CO}_{2}$, and since the $\mathrm{CO}_{2}$ output is known, the rate of oxidation of glycerol can be calculated.

The per cent glycerol converted to glucose and the per cent glucose formed from glycerol were calculated from the equations provided by Bergman, Starr, and Reulein (17). The calculated turnover does not reflect Cori cycle participation.

\section{RESULTS}

Fig. 2 shows experiments performed on two lean subjects. Subject A, after $14 \mathrm{hr}$ of fasting, had an average FFA level of $0.300 \mu \mathrm{moles} / \mathrm{ml}$ and a glycerol level of $0.06 \mu$ moles $/ \mathrm{ml}$. Calculation showed the turnover rate of glycerol to be $113.5 \mu \mathrm{moles} / \mathrm{min}$. Of this, $62.2 \%$ was immediately converted to $\mathrm{CO}_{2}$, representing $2.56 \%$ of the total $\mathrm{CO}_{2}$ output. Approximately $30.5 \%$ of the glycerol turnover was converted to glucose, representing 
only $2.4 \%$ of the glucose turnover as calculated from the mean blood glucose level and a previously established regression equation (12). In contrast, Subject $\mathrm{B}$, after 6 days of fasting, had an average FFA level of $1.56 \mu \mathrm{moles} / \mathrm{ml}$. The average glycerol turnover was $432 \mu \mathrm{moles} / \mathrm{min}$ of which $75 \%$ was converted into glucose; $67.6 \%$ of the glycerol turnover was oxidized, contributing $10.2 \%$ to the exhaled $\mathrm{CO}_{2}$.
Fig. 3 compares results obtained from the same obese subject. In experiment $\mathrm{A}$, after $12 \mathrm{hr}$ of fasting, the subject had an FFA level of $0.99 \mu$ moles $/ \mathrm{ml}$ and a glycerol level of $0.14 \mu \mathrm{moles} / \mathrm{ml}$. The glycerol turnover was $193 \mu \mathrm{moles} / \mathrm{min}$, and $43 \%$ of this was converted to glucose representing $6.9 \%$ of the total glucose turnover. In experiment $\mathrm{B}$, after 35 days of fasting, the FFA level was $2.36 \mu \mathrm{moles} / \mathrm{ml}$, and the glycerol level

A.

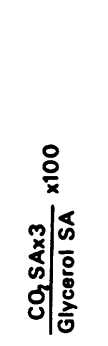

Glycerol "C(UL)
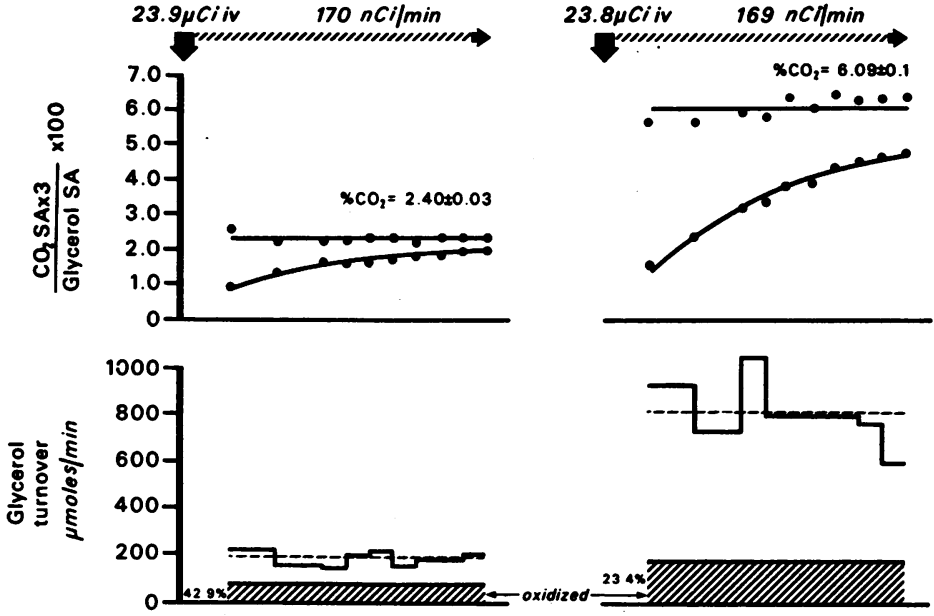

ऊั

$\left.\begin{array}{c}0.2 \\ 0.1 \\ 0\end{array}\right]$

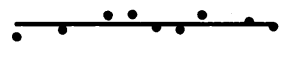

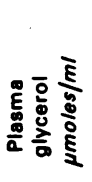

$\left.\begin{array}{l}0.5 \\ 0.4 \\ 0.3 \\ 0.2 \\ 0.1\end{array}\right]$

는

$\left.\begin{array}{c}3.0 \\ 2.0 \\ 1.0 \\ 0\end{array}\right]$
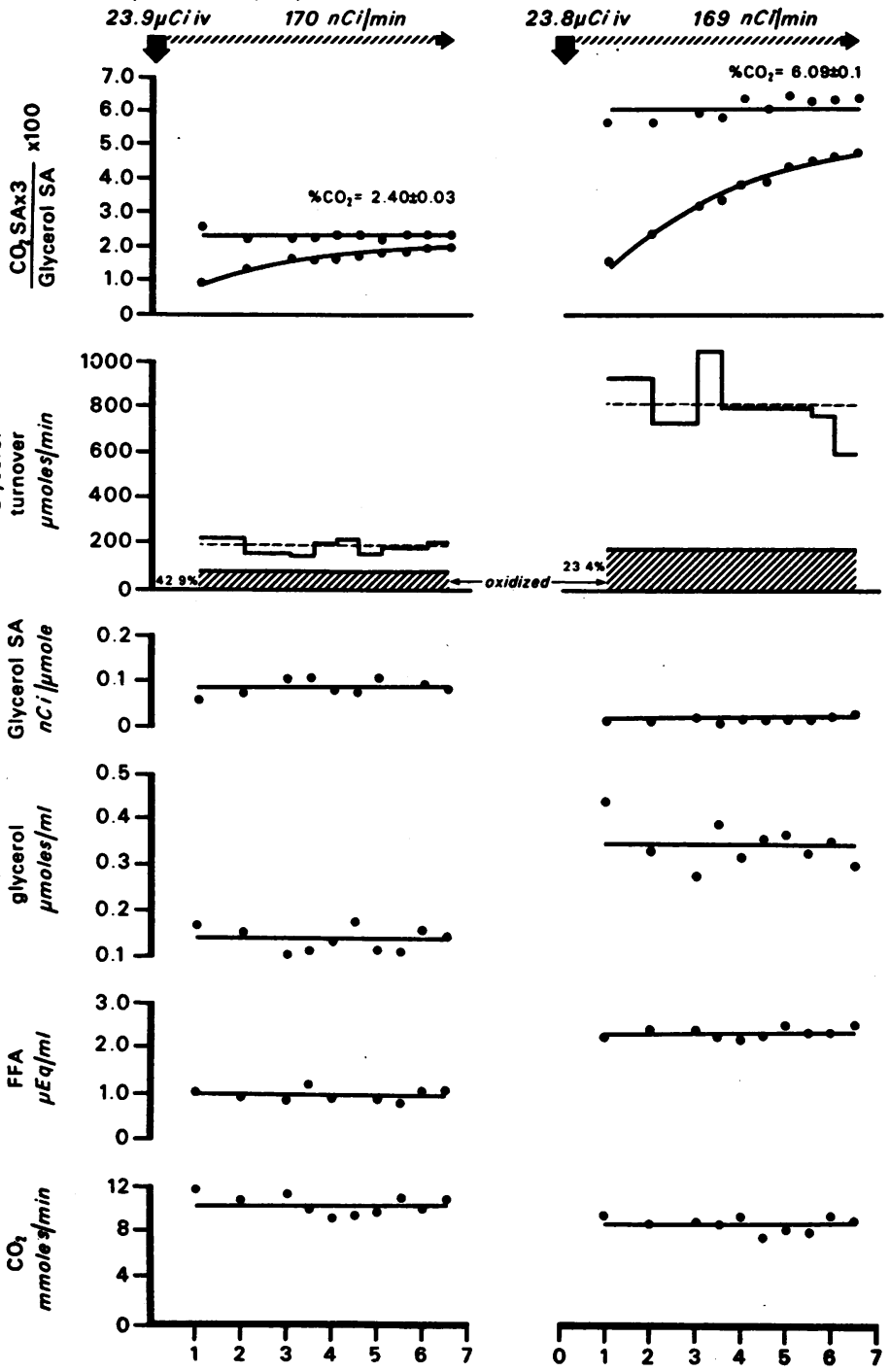

Hours
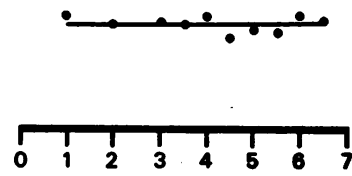

(2214.2 11 ก)।

FIgURE 3 Two experiments on subject S. W. after $12 \mathrm{hr}$ of fasting $(A)$ and 35 days of fasting $(B)$. Estimation of glycerol turnover, oxidation (hatched area), and per cent $\mathrm{CO}_{2}$ from plasma glycerol. Top graphs represent observed (curvilinear) and calculated ideal asymptotic (straight line) values of per cent $\mathrm{CO}_{2}$ from plasma glycerol. 


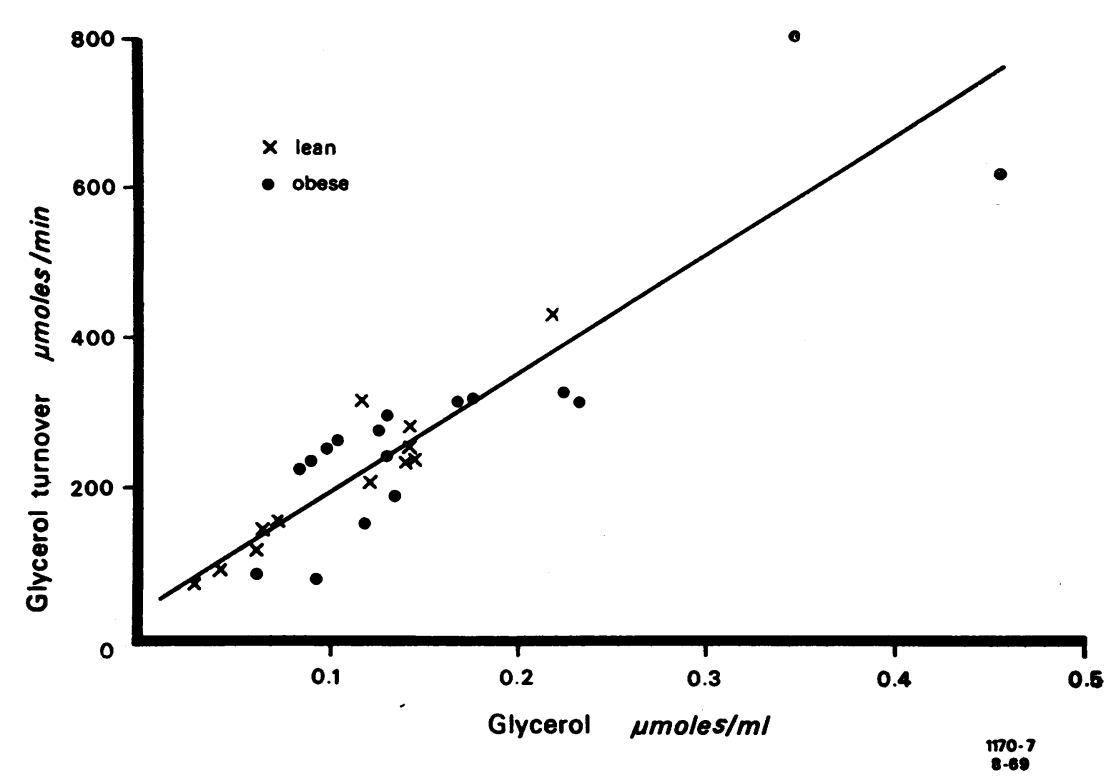

FIGURE 4 Correlation between plasma glycerol level and glycerol turnover.

was $0.34 \mu \mathrm{moles} / \mathrm{ml}$. The glycerol turnover was 806 $\mu$ moles $/ \mathrm{min}$, and $81.5 \%$ of this was converted to glucose representing $57.1 \%$ of the glucose turnover.

Fig. 4 illustrates the direct correlation of the plasma concentration and turnover values at all glycerol levels obşerved. Because of it, one can derive some estimate of glycerol turnover from the plasma level alone. The regression equation for this relationship is $y=1556 x$ +33.1 , in surprisingly good agreement with the equation of Björntorp, Bergman, Varnauskas, and Lindholm : $y=1780 x-28$ (18).

In a similar fashion the plasma FFA level and glycerol level are seen to be directly correlated (Fig.
5). Such correlation holds over the entire range of plasma FFA values seen in our experiments.

Fig. 6 indicates the correlation between glycerol turnover and the per cent of glucose that is derived from glycerol. It is likely that the latter values represent an underestimate of unknown magnitude due to the exchange of isotopic carbon of glycerol with nonisotopic carbon of pyruvate or other three carbon moieties (7).

Table I summarizes the individual results obtained in our 11 studies in lean subjects. Table II shows the findings in the 17 experiments with obese subjects. In each experiment 10 blood samples were obtained and

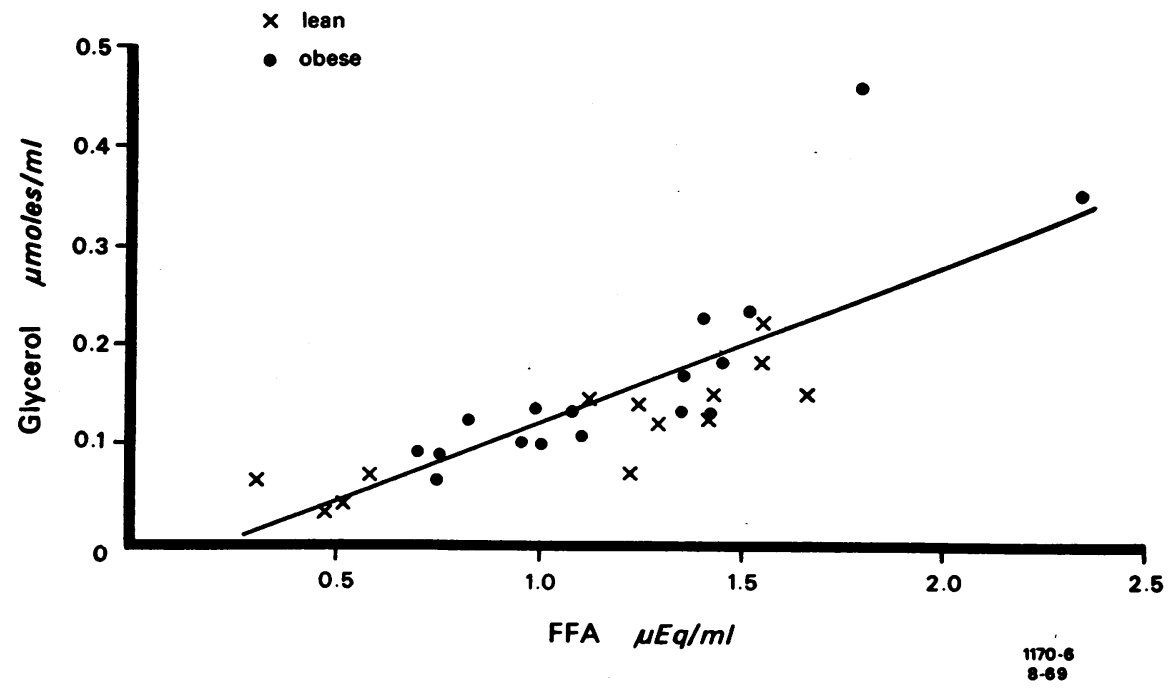

FIgURE 5 Correlation between plasma glycerol and FFA level. 


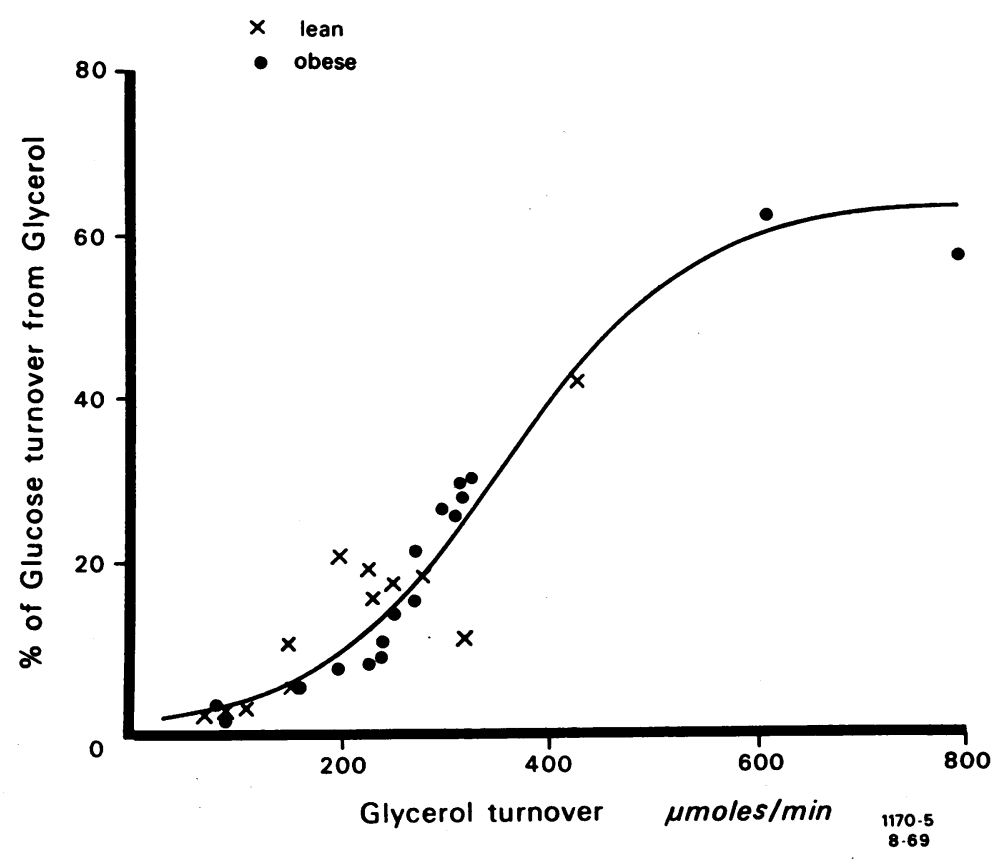

FigURE 6 Correlation between plasma glycerol turnover and per cent of glucose turnover derived from glycerol. The curve was drawn by eye.

analyzed, and the mean of their value is expressed. The exception to this is the per cent glucose from glycerol in which only the last three samples were used for the calculation. The reason for this is that the SA of the plasma glucose was still rising slightly late in the experiments. Because the SA of plasma glucose had not reached a plateau the per cent glucose from glycerol calculation is somewhat underestimated. It is to be noted (Tables I and II) that as starvation progresses, blood glycerol rises, glycerol turnover rises, and so does conversion of glycerol to glucose.

It is significant to observe that the glycerol turnover data presented here are in close agreement with those of Havel (19) and Björntorp et al. (18) who calculated their figures from experiments utilizing infusion of tritium-labeled glycerol. Pelkonen, Nikkilä, and Kekki (20) calculated glycerol turnover in a group of lean subjects via an intravenous glycerol tolerance test. Their figure of $1.7 \mu \mathrm{moles} / \mathrm{kg} \cdot \mathrm{min}$ is in good agreement with our figure of $1.5 \mu \mathrm{moles} / \mathrm{kg} \cdot \mathrm{min}$. Splanchnic and renal removal of glycerol was determined by Borchgrevink and Havel (2) to be around $100 \mu \mathrm{moles} / \mathrm{min}$, which is extremely close to our mean turnover value of $106 \mu \mathrm{moles} / \mathrm{min}$.

In Table II, data of two subjects, A. D. and S. W., were separated from those of the others since their plasma FFA and glycerol values were much higher. Inclusion of these data with the others would artificially skew the mean values as presented.
Data in Tables I and II show that the obese subjects exhibited higher plasma levels of FFA and glycerol after short fasting than did the lean subjects, $P$ $<0.001$. Excluding the two unusual obese subjects, experiments $C$ and $D$, from the mean of the values obtained there was no statistical difference between the FFA and glycerol level after long starvation. Similarly the glycerol turnover and the per cent glucose derived from glycerol were higher in the obese group after short fasting, $P<0.05$, but were not significantly different after longer fasting.

\section{DISCUSSION}

Glycerol, like glucose, serves as a substrate for oxidative and synthetic reactions. Like glucose it must first be activated by a phosphorylation reaction.

A direct measurement of glycerol oxidation has not been previously made in humans. Our experiments indicate that under no conditions did glycerol contribute more than $10 \%$ of the total respiratory $\mathrm{CO}_{2}$. It cannot, therefore, be assigned a major role as an oxidative substrate.

Our results confirm those of others in dog (21), sheep $(8)$, and man $(18,19)$ that glycerol turnover is directly proportional to the plasma glycerol. A similar relationship has also been reported for plasma FFA (22). Therefore, under appropriate conditions the plasma level alone gives some knowledge of glycerol 
TABLE I

Glycerol Metabolism in Lean Subjects

\begin{tabular}{|c|c|c|c|c|c|c|c|c|c|c|c|c|}
\hline \multirow{2}{*}{$\begin{array}{c}\text { Experi- } \\
\text { ment } \\
\text { No. }\end{array}$} & \multirow[b]{2}{*}{ Subject } & \multirow[b]{2}{*}{ Weight } & \multirow{2}{*}{$\begin{array}{l}\text { Duration } \\
\text { of } \\
\text { fasting }\end{array}$} & \multicolumn{3}{|c|}{ Plasma } & \multirow{2}{*}{$\begin{array}{l}\text { Glycerol } \\
\text { turnover }\end{array}$} & \multirow{2}{*}{$\begin{array}{l}\text { Amount } \\
\mathrm{CO}_{2} \text { from } \\
\text { plasma } \\
\text { glycerol }\end{array}$} & \multirow{2}{*}{$\begin{array}{l}\text { Glycerol } \\
\text { oxidized }\end{array}$} & \multirow{2}{*}{$\begin{array}{c}\text { Amount } \\
\text { glycerol } \\
\text { to } \\
\text { glucose }\end{array}$} & \multirow{2}{*}{$\begin{array}{l}\text { Amount } \\
\text { glucose } \\
\text { from } \\
\text { glycerol }\end{array}$} & \multirow{2}{*}{$\begin{array}{l}\text { Urinary } \\
\text { nitrogen }\end{array}$} \\
\hline & & & & FFA & Glucose & Glycerol & & & & & & \\
\hline & & kg & & $\begin{array}{c}\mu E q / \\
m l\end{array}$ & $\begin{array}{c}m g / \\
100 m l\end{array}$ & $\begin{array}{c}\text { Amoles/ } \\
\mathrm{ml}\end{array}$ & $\begin{array}{l}\text { umoles/ } \\
\min \end{array}$ & $\%$ & $\begin{array}{l}\text { Amoles/ } \\
\text { min }\end{array}$ & $\%$ & $\%$ & $g / 24 h r$ \\
\hline \multicolumn{13}{|c|}{ A. Lean subjects-short fasting } \\
\hline 1 & D. K. (M) & 79.5 & $13 \mathrm{hr}$ & 0.472 & 96.3 & 0.033 & 71.4 & 1.17 & 34.8 & 41.0 & 1.9 & \\
\hline 2 & J. M. (M) & 64.5 & $6 \mathrm{hr}$ & 0.514 & 84.5 & 0.044 & 89.4 & 2.10 & 60.7 & 32.1 & 2.2 & \\
\hline 3 & E. J. (M) & 81.8 & $6 \mathrm{hr}$ & 0.584 & 87.9 & 0.075 & 149.4 & 2.91 & 88.8 & 48.1 & 5.2 & \\
\hline 4 & N. B. (M) & 60.6 & $14 \mathrm{hr}$ & 0.297 & 92.2 & 0.065 & 113.5 & 2.55 & 70.6 & 30.5 & 2.4 & \\
\hline \multicolumn{2}{|c|}{ Average } & & & 0.467 & 90.2 & 0.054 & 105.9 & 2.18 & 63.7 & 37.9 & 2.9 & \\
\hline \multicolumn{2}{|c|}{$\pm \mathrm{SE}$} & & & 0.061 & 2.6 & 0.009 & 16.8 & 0.38 & 11.2 & 4.1 & 0.8 & \\
\hline \multicolumn{13}{|c|}{ B. Lean subjects-long fasting } \\
\hline 1 & M. M. (M) & 70.5 & $33 \mathrm{hr}$ & 1.232 & 83.2 & 0.068 & 144.7 & 2.54 & 67.7 & 90.5 & 10.1 & 16.05 \\
\hline 2 & S. Sch. (M) & 75.0 & $36 \mathrm{hr}$ & 1.671 & 64.4 & 0.176 & 281.8 & 5.02 & 163.0 & 59.3 & 17.6 & 17.13 \\
\hline 3 & M. D. (M) & 65.5 & $36 \mathrm{hr}$ & 1.132 & 74.7 & 0.146 & 250.0 & 4.94 & 140.6 & 77.4 & 17.0 & 13.85 \\
\hline 4 & E. J. (M) & 77.5 & 6 days & 1.557 & 55.0 & 0.222 & 432.3 & 10.24 & 292.0 & 75.1 & 41.9 & 12.91 \\
\hline 5 & N. B. (M) & 56.7 & 6 days & 1.427 & 49.1 & 0.125 & 202.6 & 4.72 & 100.7 & 69.5 & 21.2 & 8.43 \\
\hline 6 & W. D. (M) & 62.4 & 8 days & 1.253 & 72.2 & 0.141 & 234.0 & 5.28 & 139.4 & 75.4 & 16.1 & 7.77 \\
\hline 7 & Ch. B. (M) & 58.1 & 7 days & 1.441 & 69.1 & 0.147 & 232.6 & 4.80 & 121.4 & 84.2 & 18.9 & 7.55 \\
\hline \multirow{2}{*}{\multicolumn{2}{|c|}{$\begin{array}{l}\text { Average } \\
\pm \mathrm{SE}\end{array}$}} & & & 1.388 & 66.8 & 0.142 & 254.0 & 5.36 & 146.4 & 75.9 & 20.4 & 11.96 \\
\hline & & & & 0.072 & 4.4 & 0.014 & 33.8 & 0.88 & 26.9 & 3.8 & 3.8 & 1.52 \\
\hline
\end{tabular}

turnover. We used only fasting to induce elevation of the plasma glycerol level, and the relationship between plasma level and turnover was linear in the range of plasma FFA concentrations attained. Others have infused large quantities of glycerol as well and showed that at very high plasma levels this relationship is not valid, suggesting saturation of rate-limiting enzymes (21).

The other role of glycerol, namely, as a substrate for synthetic reactions is undoubtedly of greater significance to the organism. As cited above, both in vitro and in vivo work has emphasized how efficient is glycerol as a precursor of glucose. FFA cannot serve as a net precursor for glucose. The two organs which are the predominant gluconeogenic sites, liver and kidney, are also the sites of the greatest glycerokinase activity. Particularly during starvation is this role of glycerol manifest. In prolonged fasting, up to $100 \%$ of the glycerol turnover is diverted to glucose formation. In other experiments to be reported separately, ${ }^{1}$ the evolution of ${ }^{14} \mathrm{CO}_{2}$ during glycerol infusion to fed subjects

${ }^{1}$ Paul, P., W. M. Bortz, A. C. Haff, and W. L. Holmes. Evaluation of oxidative metabolism in lean and obese humans by the appearance of ${ }^{14} \mathrm{CO}_{2}$ during constant rate infusion of palmitate-1-14 C, D-glucose- ${ }^{14} \mathrm{C}$ (UL), and glycerol${ }^{14} \mathrm{C}$ (UL). Submitted for publication. was found to be similar to that after infusion of $\mathrm{H}^{14} \mathrm{CO}_{3}$, indicating rapid oxidation, presumably directly through the tricarboxylic acid cycle, and mixing with body bicarbonate pools. In starvation, however, the ${ }^{14} \mathrm{CO}_{2}$ evolution curve shifted until it was identical with that seen after an infusion of glucose $-{ }^{14} \mathrm{C}$, indicating that nearly all of the glycerol was being utilized for gluconeogenesis.

In Tables III and IV are presented data which enabled us to calculate the relative contributions of protein and glycerol precursors to glucose. Glucose turnover and oxidation data are given from previous experiments (12) in which glucose $-{ }^{14} \mathrm{C}$ was similarly infused as described here. These data have been published in detail previously, and are presented here to provide a direct measurement of glucose use and, further, as a comparison for the indirect calculations for glucose use that can be made from these glycerol experiments.

In fasting lean subjects, glucose turnover averaged $402 \mathrm{mmoles} / \mathrm{min}$ or $104.2 \mathrm{~g} / \mathrm{day}$, of which $70.6 \mathrm{~g}$ were oxidized directly as determined from the glucose $-{ }^{14} \mathrm{C}$ studies. The present experiments indicated that 251 mmoles/min or $65.4 \mathrm{~g}$ of glucose were oxidized, in good agreement with the value estimated directly. The figure is derived from measurement of $\mathrm{CO}_{2}$ and glu- 
TABLE II

Glycerol Metabolism in Obese Subjects

\begin{tabular}{|c|c|c|c|c|c|c|c|c|c|c|c|c|}
\hline \multirow{2}{*}{$\begin{array}{c}\text { Experi- } \\
\text { ment } \\
\text { No. }\end{array}$} & \multirow[b]{2}{*}{ Subject } & \multirow[b]{2}{*}{ Weight } & \multirow{2}{*}{$\begin{array}{l}\text { Duration } \\
\text { of } \\
\text { fasting }\end{array}$} & \multicolumn{3}{|c|}{ Plasma } & \multirow{2}{*}{$\begin{array}{l}\text { Glycerol } \\
\text { turnover }\end{array}$} & \multirow{2}{*}{$\begin{array}{l}\text { Amount } \\
\mathrm{CO}_{2} \text { from } \\
\text { plasma } \\
\text { glyecrol }\end{array}$} & \multirow{2}{*}{$\begin{array}{l}\text { Glycerol } \\
\text { oxidized }\end{array}$} & \multirow{2}{*}{$\begin{array}{c}\text { Amount } \\
\text { glycerol } \\
\text { to } \\
\text { glucose }\end{array}$} & \multirow{2}{*}{$\begin{array}{l}\text { Amount } \\
\text { glucose } \\
\text { from } \\
\text { glycerol }\end{array}$} & \multirow{2}{*}{$\begin{array}{l}\text { Urinary } \\
\text { nitrogen }\end{array}$} \\
\hline & & & & FFA & Glucose & Glycerol & & & & & & \\
\hline & & kg & & $\begin{array}{c}\mu E q / \\
m l\end{array}$ & $\begin{array}{c}m g / \\
100 m l\end{array}$ & $\begin{array}{c}\text { Amoles/ } \\
m l\end{array}$ & $\begin{array}{c}\text { umoles/ } \\
\min \end{array}$ & $\%$ & $\begin{array}{l}\text { umoles/ } \\
\min \end{array}$ & $\%$ & $\%$ & $\mathrm{~g} / 24 \mathrm{hr}$ \\
\hline \multicolumn{13}{|c|}{ A. Obese subjects-short fasting } \\
\hline 1 & J. K. (F) & 140.7 & $15 \mathrm{hr}$ & 0.766 & 93.1 & 0.092 & 236.0 & 3.78 & 123.1 & 52.5 & 8.4 & \\
\hline 2 & K. O. (M) & 111.4 & $13 \mathrm{hr}$ & 0.763 & 88.7 & 0.066 & 90.0 & 1.51 & 54.6 & 30.4 & 2.0 & \\
\hline 3 & P.S. (F) & 122.2 & $14 \mathrm{hr}$ & 0.834 & 79.3 & 0.121 & 155.1 & 2.08 & 69.9 & 43.5 & 5.5 & \\
\hline 4 & A. D. (F) & 114.8 & $13 \mathrm{hr}$ & 1.010 & 91.5 & 0.098 & 84.1 & 1.50 & 39.2 & 63.3 & 3.7 & \\
\hline 5 & S. W. (M) & 165.1 & $12 \mathrm{hr}$ & 0.987 & 77.5 & 0.139 & 193.2 & 2.40 & 82.9 & 42.8 & 6.9 & \\
\hline 6 & M. L. (M) & 114.5 & $12 \mathrm{hr}$ & 0.698 & 87.3 & 0.089 & 229.5 & 3.77 & 129.2 & 45.2 & 7.6 & \\
\hline 7 & C. G. (F) & 109.5 & $10 \mathrm{hr}$ & 0.958 & 92.0 & 0.102 & 254.1 & 5.00 & 148.0 & 81.3 & 14.2 & \\
\hline 8 & H. L. (F) & 109.9 & $24 \mathrm{hr}$ & 1.093 & 97.7 & 0.137 & 242.0 & - & - & 70.4 & 10.9 & \\
\hline 9 & J.Sh. (F) & 107.7 & $48 \mathrm{hr}$ & 1.114 & 81.1 & 0.105 & 266.4 & 4.34 & 124.3 & 73.7 & 15.6 & \\
\hline \multirow{2}{*}{\multicolumn{2}{|c|}{$\begin{array}{l}\text { Average } \\
\pm \mathrm{SE}\end{array}$}} & & & 0.914 & 87.6 & 0.105 & 194.5 & 3.05 & 96.4 & 55.9 & 8.3 & \\
\hline & & & & 0.05 & 2.3 & 0.008 & 23.1 & 0.47 & 14.1 & 5.7 & 1.5 & \\
\hline \multicolumn{13}{|c|}{ B. Obese subjects-long fasting } \\
\hline 1 & M. L. (F) & 98.6 & 23 days & 1.362 & 68.9 & 0.129 & 276.6 & 3.87 & 98.1 & 80.6 & 21.6 & 7.37 \\
\hline 2 & M. B. (F) & 79.7 & 6 days & 1.412 & 75.4 & 0.227 & 324.0 & 5.07 & 114.3 & 106.0 & 29.7 & 8.20 \\
\hline 3 & B. M. (F) & 77.0 & 13 days & 1.461 & 83.4 & 0.181 & 232.0 & 4.56 & 97.9 & 117.3 & 28.9 & 5.94 \\
\hline 4 & J.S. (F) & 99.8 & 13 days & 1.442 & 68.8 & 0.133 & 297.1 & 4.37 & 107.4 & 92.7 & 26.8 & 7.68 \\
\hline 5 & C. G. (F) & 102.0 & 15 days & 1.366 & 70.0 & 0.173 & 313.8 & 4.62 & 108.7 & 89.8 & 26.7 & 5.12 \\
\hline 6 & S. R. (F) & 119.0 & 22 days & 1.529 & 77.9 & 0.237 & 321.4 & 4.11 & 107.1 & 91.3 & 28.0 & 4.32 \\
\hline \multicolumn{2}{|c|}{ Average } & & & 1.429 & 74.1 & 0.180 & 309.3 & 4.43 & 105.6 & 96.3 & 26.9 & 6.43 \\
\hline \multicolumn{2}{|c|}{$\pm \mathrm{SE}$} & & & 0.024 & 2.4 & 0.017 & 7.7 & 0.17 & 2.6 & 5.3 & 1.2 & 0.63 \\
\hline C. & D. $(F)$ & 103.4 & 21 days & 1.803 & 69.2 & 0.459 & 612.0 & 8.62 & 203.2 & 106.0 & 62.6 & 2.96 \\
\hline D. & W. (M) & 144.1 & 35 days & 2.362 & 64.3 & 0.348 & 806.0 & 6.09 & 188.8 & 81.5 & 57.1 & 7.07 \\
\hline
\end{tabular}

cose SA, and the recognition that $76 \%$ of the glycerol is converted to glucose in the lean subjects. Urinary nitrogen excretion in the two individual glucose ${ }^{14} \mathrm{C}$ studies averaged $9.89 \mathrm{~g} /$ day, and in the glycerol ${ }^{14} \mathrm{C}$ subjects, $9.17 \mathrm{~g} /$ day (means from Table III). This could generate about $33 \mathrm{~g}$ glucose/day. Glycerol turnover in lean subjects after long fasting, which is 36.5 $\mathrm{g} /$ day, could provide a similar amount of glucose. Thus in this instance protein and glycerol provide $69.3 \mathrm{~g}$ of glucose or approximately the equivalent of the amount oxidized (Table III).

For the fasting obese subjects (Table IV) glucose turnover was $442.8 \mathrm{mmoles} / \mathrm{min}$ or $114.8 \mathrm{~g} /$ day of which $51.8 \mathrm{~g}$ was oxidized. Glucose oxidation as estimated from the glycerol experiments was $49.0 \mathrm{~g} /$ day. This is determined using the observation that with fasting in the obese, glycerol is quantitatively converted to glucose (Table II). Urinary nitrogen in these subjects indicated that $19.5 \mathrm{~g}$ of glucose could be supplied from amino acids, while $54.2 \mathrm{~g}$ of glycerol is turned over per day. In this instance protein and glycerol availability for glucose formation, $73.7 \mathrm{~g}$, exceeds glucose oxidation by approximately $20 \mathrm{~g} /$ day. In some cases, for example, C and D, Table I, 90-130 $\mathrm{g}$ of glucose could be made available from these sources. The difference in these two amounts indicates that glucose is being provided for functions other than oxidation. Prominent among these functions may be the regeneration of $\alpha$-glycerophosphate in the adipose tissue.

In our lean group which was starved for a prolonged period the plasma FFA level was $1.4 \mu$ moles $/ \mathrm{ml}$. Using the regression equation previously published which relates FFA turnover to plasma levels (22) we calculate the FFA turnover to be $1880 \mathrm{mmoles} /$ day. FFA oxidation is approximately one-third of FFA turnover, or less, indicating that FFA oxidation is about 625 mmoles/day. This estimate compares well with 650 mmoles/day which is calculated by subtracting glucose calories from BMR values. The difference between FFA turnover and oxidation, 1200 mmoles, is reesteri- 
TABLE III

Glucose Metabolism in Fasting Lean Subjects

\begin{tabular}{|c|c|c|c|c|c|c|c|c|}
\hline $\begin{array}{l}\text { Subjects } \\
\text { fasting } \\
7 \text { days }\end{array}$ & $\mathrm{CO}_{2}$ & $\begin{array}{c}\text { Plasma } \\
\text { FFA }\end{array}$ & $\begin{array}{l}\text { Plasma } \\
\text { glucose }\end{array}$ & $\begin{array}{c}\text { Glucose } \\
\text { turnover }\end{array}$ & $\begin{array}{c}\text { Glucose } \\
\text { oxidized* }\end{array}$ & $\begin{array}{c}\text { Amount } \\
\mathrm{CO}_{\text {f from }} \\
\text { plasma } \\
\text { glucose } \ddagger\end{array}$ & $\begin{array}{l}\text { Urinary } \\
\text { nitrogen }\end{array}$ & $\begin{array}{l}\text { Glycerol } \\
\text { turnover }\end{array}$ \\
\hline A. Gluc & $\begin{array}{c}\text { mmoles/ } \\
{ }^{14 i n} \\
{ }^{14} \mathrm{C} \exp \end{array}$ & $\begin{array}{c}\mu E q / \\
m l \\
\text { ents }\end{array}$ & $\begin{array}{c}m \mathrm{mg} / \\
100 \mathrm{ml}\end{array}$ & $\begin{array}{c}\text { umoles/ } \\
\text { min }\end{array}$ & $\begin{array}{c}\text { umoles/ } \\
\min \end{array}$ & $\%$ & $\mathrm{~g} / 2+\mathrm{hr}$ & $\begin{array}{c}\text { umoles/ } \\
\min \end{array}$ \\
\hline $\begin{array}{l}1 \\
2\end{array}$ & $\begin{array}{l}9.04 \\
8.00\end{array}$ & $\begin{array}{l}1.371 \\
1.829\end{array}$ & $\begin{array}{l}60 \\
62\end{array}$ & $\begin{array}{l}423 \\
381\end{array}$ & $\begin{array}{l}288 \\
257\end{array}$ & $\begin{array}{l}19.1 \\
19.4\end{array}$ & $\begin{array}{r}11.97 \\
7.80\end{array}$ & \\
\hline \multicolumn{9}{|c|}{ B. Glycerol-14 $\mathrm{C}$ experiments } \\
\hline 1 & 8.61 & 1.557 & 55 & & 263 & 23.4 & 12.91 & 432 \\
\hline 2 & 7.52 & 1.441 & 69 & & 239 & 25.3 & 7.55 & 233 \\
\hline 3 & 6.40 & 1.427 & 49 & & 180 & 22.3 & 8.43 & 203 \\
\hline 4 & 7.93 & 1.253 & 72 & & 326 & 32.7 & 7.77 & 234 \\
\hline
\end{tabular}

Sample calculation utilizing the means of the glycerol-14 $\mathrm{C}$ experiments values.

* Glucose oxidized $=$ per cent $\mathrm{CO}_{2}$ from plasma glucose $\times$ total $\mathrm{CO}_{2}=25.9 \% \times 7.62 \mathrm{mmoles} / \mathrm{min} \times 1 / 6$ (glucose molar correction factor) $=328 \mu \mathrm{moles} / \mathrm{min}$ (assuming total conversion of glycerol $\rightarrow$ glucose). Actual glucose oxidized $=328 \mu \mathrm{moles} / \mathrm{min} \times 76 \%$ (actual conversion of glycerol to glucose) $=251 \mu \mathrm{moles} / \mathrm{min}=361.4 \mathrm{mmoles} /$ day $=65.4 \mathrm{~g} /$ day.

$\ddagger$ Per cent $\mathrm{CO}_{2}$ from plasma glucose $=\mathrm{CO}_{2} \mathrm{SA} /$ glucose $\mathrm{SA}=25.9 \%$ (mean)

fied. For this purpose, the above $33.6 \mathrm{~g}$ (total glucose turnover of $104.2 \mathrm{~g} /$ day minus glucose oxidized 70.6 $\mathrm{g} /$ day) or $187 \mathrm{mmoles}$ of glucose is available. This can yield 374 mmoles of glycerol which is approximately one-third of the FFA being reesterified. It is therefore clear that there is sufficient glucose available for the reesterification of the fatty acids.

It has been demonstrated by these experiments that the triglyceride molecule of adipose tissue is incompletely cleaved in its hydrolysis yielding 4.7 molecules of fatty acid per glycerol molecule compared to the theoretical ratio of $3: 1$ for total hydrolysis. This observation can be made only in our lean group as the calculation of FFA turnover from observance of FFA level is valid only for the lean group (23). A similar ratio has previously been noted by Havel (19) and by Björntorp et al. (18). Such partial hydrolysis indicates that mono- and diglycerides exist in the adipose tissue and serve as potential acceptors for FFA reesterification as well. For this reason it is felt that

TABLE IV

Glucose Metabolism in Fasting Obese Subjects*

\begin{tabular}{|c|c|c|c|c|c|c|c|c|}
\hline $\begin{array}{c}\text { Subjects } \\
\text { fasting from } \\
5 \text { to } 35 \text { days }\end{array}$ & $\mathrm{CO}_{2}$ & $\begin{array}{c}\text { Plasma } \\
\text { FFA }\end{array}$ & $\begin{array}{l}\text { Plasma } \\
\text { glucose }\end{array}$ & $\begin{array}{l}\text { Glucose } \\
\text { turnover }\end{array}$ & $\begin{array}{l}\text { Glucose } \\
\text { oxidized }\end{array}$ & $\begin{array}{l}\text { Amount } \\
\mathrm{CO}_{2} \text { from } \\
\text { plasma } \\
\text { glucose }\end{array}$ & $\begin{array}{l}\text { Urinary } \\
\text { nitrogen } \ddagger\end{array}$ & $\begin{array}{l}\text { Glycerol } \\
\text { turnover }\end{array}$ \\
\hline A. Glucose-14 & $\begin{array}{l}\text { mmoles/ } \\
\text { min } \\
\text { perimer }\end{array}$ & $\begin{array}{c}\mu E q / \\
m l\end{array}$ & $\begin{array}{c}m g / \\
100 m l\end{array}$ & $\begin{array}{l}\text { Amoles/ } \\
\text { min }\end{array}$ & $\begin{array}{l}\text { pmoles/ } \\
\min \end{array}$ & $\%$ & $g / 24 \mathrm{hr}$ & $\begin{array}{c}\text { Mmoles/ } \\
\min \end{array}$ \\
\hline $\begin{array}{l}\text { Average } \\
\pm \mathrm{SE} \\
(\mathrm{n}=5)\end{array}$ & $\begin{array}{l}8.21 \\
0.84\end{array}$ & $\begin{array}{l}1.398 \\
0.05\end{array}$ & $\begin{array}{r}71.2 \\
4.5\end{array}$ & $\begin{array}{r}442.8 \\
24.6\end{array}$ & $\begin{array}{r}199.6 \\
8.4\end{array}$ & $\begin{array}{r}14.8 \\
1.3\end{array}$ & & \\
\hline \multicolumn{9}{|c|}{ B. Glycerol-14 $\mathrm{C}$ experiments } \\
\hline $\begin{array}{l}\text { Average } \\
\pm \mathrm{SE} \\
(\mathrm{n}=8)\end{array}$ & $\begin{array}{l}7.37 \\
9.25\end{array}$ & $\begin{array}{l}1.592 \\
0.12\end{array}$ & $\begin{array}{r}72.1 \\
2.2\end{array}$ & & $\begin{array}{r}188.9 \\
7.8\end{array}$ & $\begin{array}{r}15.6 \\
9.8\end{array}$ & $\begin{array}{l}5.66 \\
0.55\end{array}$ & $\begin{array}{r}409.2 \\
68.2\end{array}$ \\
\hline
\end{tabular}

* Values are means $\pm \mathrm{SE} ; \mathrm{n}=$ number of subjects.

$\ddagger \mathrm{n}=11$ subjects. 
the plasma glycerol level per se is not a satisfactory measure of lipolysis.

It has been proposed that the obese individual in the fed state exhibits similar metabolic changes to fasting lean individuals (24). In other words, the obese subject is primed for starvation. Observations from these experiments are consistent with this hypothesis. After short fasting the obese group has higher blood glycerol levels and higher glycerol turnover than the lean. Further, in the obese, glycerol contributes relatively more to glucose formation, even after short fasting. In the fasting state (Table II), it can be seen that glycerol is quantitatively more important than protein as a source for new glucose. Utilizing the data in Tables I and II one calculates that with fasting in the obese subjects, glycerol represented $79.3 \%$ of the total (glycerol and protein) gluconeogenic substrates. In the comparable lean group, glycerol accounts for only $38 \%$ of the same total. Conversely, the obese rely less on protein catabolism as a source of glucose carbon. The ability of fat individuals to spare protein breakdown during acute starvation has previously been noted (25). The increased availability of glycerol to supply glucose is though to be at least partially responsible for this.

\section{ACKNOWLEDGMENTS}

The authors gratefully acknowledge the technical assistance of Mary Anne Nuthall, Maureen Donohue, Ruth Hughes, Susan Richter, and Maria Walther. This work was supported by Grants AM-13527 and FR-5585 from the National Institutes of Health.

\section{REFERENCES}

1. Shafrir, E., and E. Gorin. 1963. Release of glycerol in conditions of fat mobilization and deposition. Metab. (Clin. Exp.). 12 : 580.

2. Borchgrevink, C. F., and R. J. Havel. 1963. Transport of glycerol in human blood. Proc. Soc. Exp. Biol. Med. 113: 946 .

3. Vaughn, M. 1962. The production and release of glycerol by adipose tissue incubated in vitro. J. Biol. Chem. $237: 3354$

4. Chambers, W. H., and H. J. Deuel, Jr. 1925. The metabolism of glycerol in phlorizin diabetes. J. Biol. Chem. 65: 21 .

5. Teng, C.-T., M. L. Karnovsky, B. R. Landau, A. B. Hastings, and F. B. Nesbett. 1953. Metabolism of $C^{14}$ labeled glycerol and pyruvate by liver in vitro. J. Biol. Chem. 202: 705.

6. Nikkilä, E. A., and K. Ojala. 1964. Gluconeogenesis from glycerol in fasting rats. Life Sci. 3: 243 .
7. Winkler, B.. I. Rathgeb, R. Steele, and N. Altszuler. 1970. Conversion of glycerol to glucose in the normal dog. Amer. J. Physiol. 219: 497.

8. Bergman, E. N. 1968. Glycerol turnover in the nonpregnant and ketotic pregnant sheep. Amer. J. Physiol. $215: 865$.

9. Issekutz, B., H. I. Miller, P. Paul, and K. Rodahl. 1964. Source of fat oxidation in exercising dogs. Amer. $J$. Physiol. 207: 583.

10. Fredrickson, D. S., and K. Ono. 1958. An improved technique for assay of $\mathrm{C}^{14} \mathrm{O}_{2}$ in expired air using the liquid scintillation counter. J. Lab. Clin. Med. 51: 147.

11. Miller, H. I., B. Issekutz, Jr., and K. Rodahl. 1963. Effect of exercise in the metabolism of fatty acids in the dog. Amer. J. Physiol. 205: 167.

12. Paul, P., and W. M. Bortz. 1969. Turnover and oxidation of plasma glucose in lean and obese humans. Metab. (Clin. Exp.). 18: 570.

13. Bray, G. A. 1960 . A simple efficient liquid scintillator for counting aqueous solution in a liquid scintillation counter. Anal. Biochem. 1: 279.

14. Kessler, G., and H. Lederer. 1966. Automation in analytical chemistry. Mediad Inc., White Plains, N. Y.

15. Winkler, B., R. Steele, C. Bjerknes, I. Rathgreb, and N. Altszuler. 1967. Isolation of a pure glycerol-C ${ }^{14}$ derivative for measurement of glycerol turnover. J. Appl. Physiol. 23 : 752.

16. Issekutz, B., P. Paul, H. I. Miller, and W. Bortz. 1968. Oxidation of plasma FFA in lean and obese humans. Metab. (Clin. Exp.). 17: 62 .

17. Bergman, E. N., D. J. Starr, and S. S. Reulein, Jr. 1968. Glycerol metabolism and gluconeogenesis in the normal and hypoglycemic ketotic sheep. Amer. J. Physiol. $215: 874$.

18. Björntorp, P., H. Bergman, E. Varnauskas, and B. Lindholm. 1969. Lipid mobilization in relation to body composition in man. Metab. (Clin. Exp.). 18: 840.

19. Havel, R. J. 1965. Some influences of the sympathetic nervous system and insulin in mobilization of fat from adipose tissue: studies of the turnover rates of free fatty acids and glycerol. Ann. N. Y.Acad. Sci. 131: 91.

20. Pelkonen, R., E. A. Nikkilä, and M. Kekki. 1967. Metabolism of glycerol in diabetes mellitus. Diabetologia. 3:1.

21. Winkler, B., R. Steele, and N. Altszuler. 1969. Relationship of glycerol uptake to plasma glycerol concentration in the normal dog. Amer. J. Physiol. 216: 191.

22. Armstrong, D. T., R. Steele, N. Altszuler, A. Dunn, J. S. Bishop, and A. C. DeBodo. 1964. Regulations of plasma free fatty acid turnover. Amer. J. Physiol. 201: 9.

23. Issekutz, B., W. M. Bortz, N. I. Miller, and P. Paul. 1967. Turnover rate of plasma FFA in humans and in dogs. Metab. (Clin. Exp.). 16: 1001.

24. Bortz, W. M. 1969. Metabolic consequences of obesity. Ann. Intern. Med. $71: 833$

25. Kekwick, A., G. L. S. Pawan, and T. M. Chalmers. 1959. Resistance to ketosis in obese subjects. Lancet. 2: 1157. 